\title{
Penerapan Strategi Scaffolding terhadap Kemampuan Pemecahan Masalah Matematis Siswa Kelas VIII SMP
}

\author{
Febri Nanda Ramadhani1 ${ }^{1}$, Mira Amelia Amri², Maria Para Siska ${ }^{3 *}$ \\ 1,2,3 STKIP YDB Lubuk Alung, Sumatera Barat, Indonesia \\ *Corresponding Author
}

\begin{tabular}{|c|}
\hline Informasi Artikel \\
\hline $\begin{array}{l}\text { Diterima Redaksi: } 12 \text { Februari } 2021 \\
\text { Revisi Akhir: } 15 \text { Maret } 2021 \\
\text { Diterbitkan Online: } 30 \text { Juni } 2021\end{array}$ \\
\hline Kata Kunci \\
\hline $\begin{array}{l}\text { Pemecahan Masalah, } \\
\text { Strategi Scaffolding. }\end{array}$ \\
\hline Korespondensi \\
\hline
\end{tabular}

\begin{abstract}
A B S T R A C T
This study aims to determine the application of scaffolding strategy to students' mathematical problem solving in class VIII SMP. This type of research is a true-experimental study with a randomized posttest only control group design. The population in this study were students of class VIII SMP in Padang Pariaman Regency. Sampling was done by random sampling technique. Data analysis of mathematical problem solving abilities carried out in the cognitive domain. Based on data analysis, it can be concluded that students' mathematical problem solving abilities using scaffolding strategies are better than mathematical problem solving abilities using scientific approaches.

Penelitian ini bertujuan untuk mengetahui penerapan strategi scaffolding terhadap pemecahan masalah matematis siswa di kelas VIII SMP. Jenis penelitian ini merupakan penelitian true-eksperimen dengan rancangan penelitian randomized posttest only control group design. Populasi dalam penelitian ini adalah siswa kelas VIII SMP di Kabupaten Padang Pariaman. Pengambilan sampel dilakukan dengan teknik random sampling. Analisis data kemampuan pemecahan masalah matematis yang dilakukan pada ranah kognitif. Berdasarkan analisis data, dapat disimpulkan bahwa kemampuan pemecahan masalah matematis siswa yang menggunakan strategi scaffolding lebih baik dari kemampuan pemecahan masalah matematis yang menggunakan pendekatan saintifik.

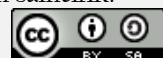

02021 by the authors. Submitted for possible open access publication under the terms and conditions of the Creative Commons Attribution-ShareAlike 4.0 International License-(CC-BY-SA)
(https://creativecommons.org/licenses/by-sa/4.0/)
\end{abstract}

\section{Pendahuluan}

Matematika merupakan salah satu ilmu pengetahuan yang sangat dibutuhkan dalam kehidupan manusia. Oleh sebab itu, hampir pada setiap jenjang pendidikan mulai dari pendidikan pra sekolah sampai ke perguruan tinggi pelajaran matematika selalu diberikan. Hal ini dikarenakan oleh kedudukan ilmu matematika itu sendiri yaitu sebagai ratu dan pelayan ilmu. Hal ini, seperti yang dinyatakan oleh [1] bahwa matematika tumbuh dan berkembang sebagai suatu ilmu serta ikut menunjang keberhasilan ilmu-ilmu lainnya. Matematika diperlukan dalam proses mencapai keberhasilan pada ilmu pengetahuan lainnya dan perkembangan teknologi. Selain berperan dalam bidang ilmu pengetahuan dan teknologi matematika juga berperan dalam masyarakat, misalnya banyak persoalan dalam kehidupan sehari-hari yang memerlukan kemampuan menghitung dan mengukur. Hal ini menunjukkan bahwa begitu pentingnya peranan matematika dalam bidang ilmu pengetahuan, teknologi, dan masyarakat.

Mengingat begitu pentingnya pendidikan matematika, maka kurikulum di Indonesia menitikberatkan pada mata pelajaran tersebut, diberikan kepada peserta didik mulai dari sekolah dasar, menengah, sampai perguruan tinggi. Menurut [2] mata pelajaran matematika merupakan mata pelajaran dasar, di sekolah dasar ataupun sekolah menengah, mempelajari matematika adalah penting karena dalam kehidupan sehari-hari kita tidak boleh mengelak dari aplikasi matematika bukan itu saja matematika juga mampu mengembangkan kesadaran tentang nilai-nilai yang secara esensial terdapat didalamnya. Belajar matematika dapat membekali peserta didik dengan kemampuan berfikir logis, analitis, sistematis, kritis dan kreatif serta kemampuan bekerjasama. Selain itu, mempelajari matematika juga ditujukan agar siswa mampu menggunakan penalaran pada pola dan sifat, memecahkan masalah yang meliputi 
kemampuan memahami masalah, merancang model matematika menyelesaikan model dan menafsirkan solusi yang diperoleh.

Guru matematika mempunyai peran penting dalam tercapainya tujuan pembelajaran matematika. Seorang guru perlu mengetahui bagaimana cara menjadikan siswa aktif dalam belajar yaitu menciptakan stimulus yang dapat menantang daya pikir siswa sehingga dapat merespon pembelajaran dengan baik. Upaya yang telah ditempuh guru matematika adalah merancang dan mempersiapkan pembelajaran yang sesuai dengan kondisi dan kemampuan siswa serta sesuai dengan materi yang diajarkan agar hasil belajar matematika meningkat.

Salah satu kemampuan yang harus ditingkatkan siswa yaitu kemampuan pemecahan masalah. Kemampuan pemecahan masalah merupakan hal yang penting dalam pendidikan matematika, sehingga siswa perlu dibekali keterampilan untuk mampu memecahkan masalah yang dihadapinya. Ditegaskan [3] dalam Kurikulum 2013 bahwa pembelajaran matematika selain menekankan penguasaan konsep, tujuan lainnya adalah: melatih cara berpikir dan bernalar dalam menarik kesimpulan, misalnya melalui kegiatan penyelidikan, eksplorasi, eksperimen, menunjukkan kesamaan, perbedaan, konsisten, dan inkonsistensi, mengembangkan aktivitas kreatif yang melibatkan imajinasi, intuisi, dan penemuan dengan mengembangkan pemikiran divergen, orisinil, rasa ingin tahu, membuat prediksi dan dugaan, serta mencoba-coba, dan mengembangkan kemampuan memecahkan masalah. Mengembangkan kemampuan menyampaikan informasi atau mengkomunikasikan gagasan antara lain melalui pembicaraan lisan, grafik, peta, diagram, dalam menjelaskan gagasan. Selain itu, kemampuan pemecahan masalah juga diperlukan untuk keberhasilan siswa di sekolah.

Kenyataan yang ditemukan di SMP, kemampuan pemecahan masalah matematika masih rendah. Rendahnya kemampuan pemecahan masalah matematika siswa dapat dilihat dari hasil tes observasi yang diberikan tentang Sistem Persamaan Linear Dua Variabel (SPLDV) pada Siswa kelas VIII.2, yang terlihat pada Gambar 1.

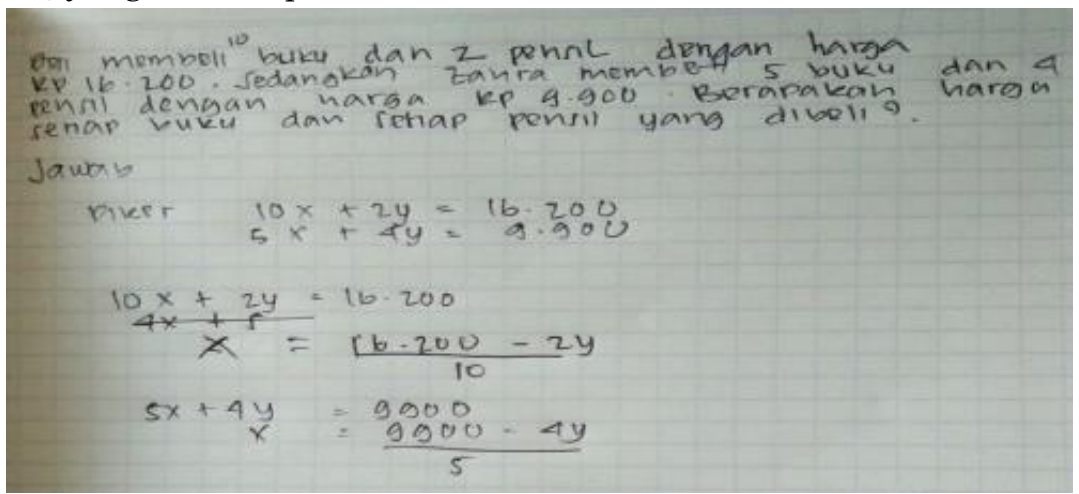

Gambar 1. Jawaban Siswa

Penyelesaian yang diberikan siswa pada Gambar 1. menunjukkan bahwa siswa belum mampu memahami masalah yang diberikan karena siswa tidak dapat mengetahui unsur-unsur yang harus diselesaikan dalam soal. Siswa sudah mampu menyusun atau merencanakan strategi dalam menyelesaikan soal, tetapi siswa belum mampu dalam menerapkan strategi tersebut untuk mendapatkan solusi dalam penyelesaiannya sehingga jawaban yang diberikan siswa tidak benar atau salah.

Berdasarkan hasil observasi pembelajaran matematika di kelas VIII di salah satu SMP di Kabupaten Padang Pariaman, faktor penyebab rendahnya kemampuan pemecahan masalah matematika siswa karena kurangnya pemahaman siswa terhadap konsep-konsep matematika. Siswa kurang bekerjasama (diskusi) dalam pembelajaran sehingga pendapat siswa kurang tersalurkan dalam pembelajaran. Kemampuan siswa dalam merancang soal ke dalam model matematika yang kurang baik. Siswa tidak terbiasa dengan konsep pemecahan masalah, 
sehingga siswa kurang memahami materi pembelajaran, dan daya serap siswa dalam memahami materi masih rendah.

Menyadari pentingnya kemampuan pemecahan masalah, maka guru harus mengupayakan menerapkan pembelajaran yang dapat mencapai kemampuan pemecahan masalah matematika yaitu dengan strategi scaffolding. [4] menyatakan bahwa "scaffolding berarti memberikan kepada anak sejumlah besar dukungan selama tahap-tahap awal pembelajaran, kemudian mengurangi bantuan dan memberikan kesempatan kepada anak untuk mengambil tanggung jawab yang semakin besar segera setelah ia mampu melakukan tugas tersebut secara mandiri”. [4] mengemukakan "Scaffolding adalah interaksi antara orang-orang dewasa dan anak-anak yang memungkinkan anak-anak untuk melaksanakan sesuatu di luar usaha siswanya”. Interaksi sosial yang terjadi di kelas ketika saling bertukar pendapat antar siswa dalam memecahkan masalah tersebut, maka terjadi scaffolding. Siswa yang mengalami kesulitan tersebut terbantu oleh teman yang pandai. Secara teknis, scaffolding dalam belajar adalah membantu siswa pada awal belajar untuk mencapai pemahaman dan keterampilan kemudian secara perlahan-lahan bantuan tersebut dikurangi sampai akhirnya siswa dapat belajar mandiri dan menemukan pemecahan bagi tugas-tugasnya.

Penerapan strategi ini diharapkan agar siswa lebih termotivasi dalam belajar, siswa berani mengeluarkan ide/pendapat dan siswa yang sudah paham mau berbagi pengetahuan dengan siswa yang belum paham, sehingga siswa mampu belajar secara mandiri dalam menyelesaikan soal atau masalah yang diberikan. Scaffolding selalu digunakan untuk mendukung pembelajaran dalam berbasis masalah. [4] menyatakan secara umum langkah-langkah pembelajaran scaffolding, yaitu: menjelaskan materi pembelajaran, menentukan Zone of Proximal Development (ZPD) atau level perkembangan siswa berdasarkan tingkat kognitifnya dengan melihat nilai hasil belajar sebelumnya, mengelompokkan siswa menurut ZPD-nya, memberikan tugas belajar berupa soal-soal berjenjang yang berkaitan dengan materi pembelajaran, mendorong siswa untuk bekerja dan belajar menyelesaikan soal-soal secara mandiri dengan berkelompok, memberikan bantuan berupa bimbingan, motivasi, pemberian contoh, kata kunci, atau hal yang dapat memancing siswa ke arah kemandirian belajar, mengarahan siswa yang memiliki ZPD yang tinggi untuk membantu siswa yang memiliki ZPD yang rendah, dan menyimpulkan pelajaran dan memberikan tugas-tugas. Berdasarkan hasil penelitian [5] Scaffolding merupakan suatu cara yang dapat digunakan guru untuk meminimalis kesulitan siswa dalam belajar matematika ataupun dalam pemecahan masalah matematika. Belajar dalam konstruktivis adalah bentukan hasil pikiran siswa sendiri, oleh karena itu scaffolding yang diberikan guru bukanlah menyelesaikan masalah siswa tetapi merupakan merupakan bantuan atau arahan dengan mengkaitkan kesulitan siswa dalam ZPD untuk meningkatkan perkembangan kemampuan potensial.

Scaffolding juga dapat meningkatkan kemampuan komunikasi matematis siswa. Hal ini sesuai dengan hasil penelitian [6] yang menyatakan bahwa "Kemampuan komunikasi matematis siswa mengalami peningkatan setelah diberi scaffolding berbasis kearifan lokal. Subjek R-03 sebelum diberi scaffolding berbasis kearifan lokal tidak mampu memenuhi indikator kemampuan komunikasi matematis dengan baik, tetapi hanya mampu memahami masalah dan mengevaluasi ide-ide matematika dalam bentuk tulisan, lisan, atau gambar meskipun belum sempurna. Setelah mendapat scaffolding berbasis kearifan lokal, subjek mulai mampu memahami masalah dan mengevaluasi ide-ide matematika dalam bentuk tulisan, lisan, atau gambar, mengekspresikan ide-ide matematika dalam bentuk tulisan, lisan, atau gambar, dan membuat model matematika tetapi masih kesulitan dalam membuat penyelesaian masalah secara sistematis. Subjek S-01 sebelum mendapatkan scaffolding berbasis kearifan lokal belum mampu memenuhi indikator kemampuan komunikasi matematis secara sempurna. Namun, setelah diberi scaffolding berbasis kearifan lokal, subjek mampu memahami masalah dan mengevaluasi 
ide-ide matematika dalam bentuk tulisan, lisan, atau gambar dan mengekspresikan ide-ide matematika dalam bentuk tulisan, lisan, atau gambar, tetapi belum maksimal dalam membuat model matematika berdasarkan permasalahan dan menyelesaikannya karena masih menemui kendala untuk meyelesaikan masalah secara sistematis. Sebelum mendapatkan scaffolding berbasis kearifan lokal, subjek T-01 hampir memenuhi seluruh indikator kemampuan komunikasi matematis walaupun belum sempurna. Setelah subjek diberi scaffolding berbasis kearifan lokal, subjek mampu memenuhi seluruh indikator kemampuan komunikasi matematis, tetapi pada indikator mengekspresikan ide-ide matematika dalam bentuk tulisan, lisan, atau gambar belum dikuasai secara seluruhnya dalam hal memberikan alasan yang logis dari jawaban yang diberikan dengan bahasanya sendiri."

Menurut langkah-langkah tersebut penerapan strategi scaffolding dalam proses pembelajaran matematika dilakukan dengan mengelompokkan siswa berdasarkan tingkat kognitifnya, guru memberikan soal kepada masing-masing kelompok untuk didiskusikan dengan kelompoknya. Selama proses diskusi guru memantau dan memberikan bantuan dengan bertahap, dan mendorong siswa untuk bekerja dan menyelesaikan soal secara mandiri. Tahaptahap scaffolding yang baik menurut [7] adalah: pada tahap memahami masalah (understanding the problem), yaitu subjek diminta membaca ulang masalah dengan baik dan teliti. Selanjutnya, memberikan pertanyaan arahan kepada subjek agar subjek memahami masalah. Sedangkan pada tahap membuat perencanaan penyelesaian masalah (devising a plan), bentuk scaffolding yang diberikan pada subjek adalah memberikan kesempatan pada subjek untuk bernalar dan menyusun kembali rancangan jawaban yang tepat. Pada tahap melaksanakan perencanaan (carrying out the plan), bentuk scaffolding yang diberikan yaitu meminta subjek untuk memperhatikan konsep aljabar dan teliti dalam mengoperasikan penjumlahan operasi bentuk aljabar, kemudian diberikan scaffolding untuk membantu siswa membuat kesimpulan dengan memberikan beberapa pertanyaan yang dapat merangsang siswa kepada kesimpulan yang diinginkan."

Polya dalam [1] mengemukakan dalam pemecahan suatu masalah terdapat empat langkah yang harus dilakukan yaitu: memahami masalah, merencanakan pemecahannya, melaksanakan rencana untuk menyelesaikan masalah, dan memeriksa kembali hasil penyelesaian masalah. Pemecahan masalah merupakan komponen yang sangat penting dalam proses pembelajaran matematika. Pemecahan masalah merupakan aktivitas dalam menyelesaikan suatu tugas matematika yang mana cara penyelesaiannya belum diketahui sebelumnya dengan pasti. Dalam kegiatan pemecahan masalah perlu adanya kemampuan kognitif yang tinggi, dan harus melakukan proses mental dalam pikirannya dengan cara mengaitkan antara satu konsep dengan konsep yang lainnya. Hal ini, tentunya akan menyebabkan sulitnya siswa memahami pemecahan masalah matematika dengan benar dan cepat. Untuk mengatasi masalah tersebut, salah satu cara yang dapat dilakukan adalah dengan memberi bantuan belajar kepada siswa (Scaffolding). Peran guru dalam strategi Scaffolding sangat penting, yaitu guru membantu siswa dalam menuntaskan tugas atau konsep pada yang awalnya tidak mampu diperoleh secara mandiri. Sesuai dengan kurikulum 2013 dimana siswa tidak terlepas dari bantuan dan dukungan dari guru sebagai orang yang berkompeten. Bantuan dari guru diperlukan akan tetapi harus semakin berkurang dengan bertambah dewasanya atau tinggi kelasnya. Ketika siswa dianggap telah mampu menyelesaikan tugas-tugasnya maka guru berhenti memberi bantuan, agar siswa melanjutkan tugasnya secara mandiri.

Tujuan dari penelitian ini adalah untuk mengetahui penerapan strategi Scaffolding terhadap kemampuan pemecahan masalah matematis siswa Kelas VIII SMP. 


\section{Metode Penelitian}

Jenis penelitian yang digunakan adalah penelitian true-eksperimen. Penelitian ini dilakukan terhadap dua kelas yaitu kelas eksperimen dan kelas kontrol. Perlakuan yang diberikan pada kelas eksperimen yaitu dengan menerapkan strategi scaffolding dan pada kelas kontrol dengan menerapkan pendekatan saintifik.

Populasi pada penelitian ini adalah seluruh siswa kelas VIII SMP di Kabupaten Padang Pariaman yang terdaftar pada tahun pelajaran 2018/2019. Berdasarkan sumber yang didapatkan jumlah seluruh siswa kelas VIII SMP sebanyak 72 siswa yang terdiri dari 3 kelas. Pengambilan sampel pada penelitian ini dengan cara random sampling yaitu pengambilan sampel secara acak dengan menggunakan undian. Kelas terambil pertama kelas eksperimen yaitu kelas VIII ${ }_{1}$ dan terambil kedua adalah kelas kontrol yaitu kelas VIII $_{2}$.

Instrumen penelitian berupa tes akhir belajar pada ranah kognitif. Soal tes berbentuk essai. Tes disusun berdasarkan kisi-kisi soal yang berpedoman pada pokok bahasan yang diajarkan dalam penelitian ini. Langkah-langkah yang dilakukan untuk melihat apakah soal tes layak digunakan, yaitu a) menyusun tes, b) uji coba tes, c) analisis uji coba tes. Uji coba tes dilakukan di Sekolah yang berbeda.

\section{Hasil dan Pembahasan}

\subsection{Hasil}

Deskripsi data yang akan disajikan dari hasil penelitian ini ialah data hasil belajar siswa terhadap kemampuan pemecahan masalah yang menggunakan strategi scaffolding pada kelas eksperimen dan pendekatan saintifik pada kelas kontroldapat dilihat pada Tabel 1.

Tabel 1. Deskripsi Data Tes Akhir Kedua Kelas Sampel

\begin{tabular}{lllllll}
\hline Kelas & $\mathbf{N}$ & $\overline{\mathbf{x}}$ & $\mathbf{s}^{2}$ & $\mathbf{S}$ & $\mathbf{X}_{\max }$ & $\mathbf{X}_{\min }$ \\
\hline Eksperimen & 25 & 73,16 & 166,81 & 12,92 & 80 & 35 \\
Kontrol & 22 & 50,45 & 140,64 & 11,86 & 70 & 17 \\
\hline
\end{tabular}

Berdasarkan Tabel 1 dapat dilihat bahwa nilai rata-rata hasil belajar siswa ranah kognitif pada kelas eksperimen lebih tinggi dibandingkan kelas kontrol, sedangkan nilai variansi dan simpang baku hampir sama. Perhitungan uji normalitas kedua kelas sampel maka diperoleh harga $\mathrm{L}_{0}$ dan Lt pada taraf nyata 0,05 seperti terlihat pada Tabel 2 .

Tabel 2. Uji Normalitas Kedua Kelas Sampel

\begin{tabular}{lllll}
\hline Kelas & $\mathbf{N}$ & $\mathbf{L}_{\text {hitung }}$ & $\mathbf{L}_{\text {tabel }}$ & Keterangan \\
\hline Eksperimen & 25 & 0,168 & 0,173 & Berdistribusi Normal \\
Kontrol & 30 & 0,152 & 0,179 & Berdistribusi Normal \\
\hline
\end{tabular}

Berdasarkan Tabel 2 diperoleh $\mathrm{L}_{0}<\mathrm{L}_{t}$ hal ini dapat disimpulkan bahwa data hasil belajar matematika siswa pada kedua kelas sampel berdistribusi normal.

Perhitungan uji homogenitas yang dilakukan dengan menggunakan rumus uji-F seperti yng terlihat pada Tabel 3 .

Tabel 3. Uji Homogenitas kelas eksperimen dan kelas kontrol

\begin{tabular}{cccc}
\hline Kelas & $\mathbf{F}_{\text {hitung }}$ & $\mathbf{F}_{\text {tabel }}$ & Keterangan \\
\hline Kelas Eksperimen dan Kelas Kontrol & 1,19 & 2,05 & Homogen \\
\hline
\end{tabular}


Berdasarkan Tabel 3 diperoleh harga $\mathrm{F}_{\mathrm{h}}<\mathrm{F}_{\mathrm{t}}$. Dapat disimpulkan bahwa kelas eksperimen dan kelas kontrol mempunyai variansi yang homogen.

Berdasarkan hasil analisis data tes akhir kedua kelas sampel diperoleh kesimpulan bahwa kedua kelas sampel berdistribusi normal dan mempunyai varians yang homogen, maka untuk menguji hipotesis digunakan uji-t. Analisis uji-t maka diperoleh $t_{\text {hitung }}=6,09$ dan $t_{\text {tabel }}=1,67$ dengan taraf kepercayaan $95 \% \mathrm{~d}_{\mathrm{k}}=45$. Ini berarti thitung berada diluar penerimaan $\mathrm{H}_{0}$ karena $t_{\text {hitung }}>t_{\text {tabel }}$, sehingga $\mathrm{H}_{\mathrm{i}}$ diterima.

Pengujian hipotesis untuk pemecahan masalah matematis siswa digunakan uji z. Analisis uji-z diperoleh dapat dilihat pada Tabel 4.

Tabel 4. Uji Proporsi Kelas Eksperimen dan Kelas Kontrol

\begin{tabular}{ccc}
\hline Indikator & $\mathbf{Z}_{\text {hitung }}$ & $\mathbf{Z}_{\text {tabel }}$ \\
\hline $\mathbf{A}$ & 1,775 & 1,645 \\
$\mathbf{B}$ & 1,992 & 1,645 \\
$\mathbf{C}$ & 2,136 & 1,645 \\
$\mathbf{D}$ & 1,719 & 1,645 \\
\hline
\end{tabular}

Berdasarkan Tabel 4 diperoleh harga Z Zitung $>$ Ztabel pada taraf nyata $a=0,05$. Kriteria pengujian hipotesis untuk terima $\mathrm{H}_{0}$ jika $Z_{\text {hitung }}<Z_{\text {tabel, }}$, dalam hal ini $\mathrm{H}_{0}$ ditolak dan $\mathrm{H}_{\mathrm{i}}$ diterima.

Berdasarkan pengujian hipotesis tersebut dapat disimpulkan bahwa kemampuan pemecahan masalah matematis siswa yang menggunakan strategi scaffolding lebih baik dari pada menggunakan pendekatan saintifik di kelas VIII SMP.

\subsection{Pembahasan}

Berdasarkan analisis data dan hasil tes kemampuan pemecahan masalah diperoleh ratarata hasil belajar siswa ranah kognitif pada kelas eksperimen lebih tinggi dibandingkan kelas kontrol. Rata-rata hasil tes akhir kelas eksperimen adalah 73,16 sedangkan kelas kontrol adalah 50,45 pengujian hipotesis untuk melihat pemecahan masalah siswa dengan menggunakan uji-t didapat harga $t_{\text {hitung }}=6,09$ dan $t_{\text {tabel }}=1,68$ pada taraf kepercayaan $95 \%$. Ini berarti $t_{\text {hitung }}$ berada diluar penerimaan $\mathrm{H}_{0}$ karena $t_{\text {hitung }}>t_{\text {tabel }}$ sehingga $\mathrm{H}_{\mathrm{i}}$ diterima, Pada pengujian hipotesis untuk pemecahan masalah matematis siswa diperoleh dari setiap indikator soal tes yang mengandung indikator pemecahan masalah menggunakan uji-z, sehingga didapat $\mathrm{z}_{\mathrm{h}}$ indikator $\mathrm{A}=1,775, \mathrm{z}_{\mathrm{h}}$ indikator $\mathrm{B}=1,992, \mathrm{z}_{\mathrm{h}}$ indikator $\mathrm{C}=2,136, \mathrm{z}_{\mathrm{h}}$ indikator $\mathrm{D}=1,719$ dengan $a=0,05$ diperoleh $z_{\text {tabel }}=1,645$ sehingga disimpulkan $z_{\text {hitung }}>z_{\text {tabel }}$ ini berarti $z_{\text {hitung }}$ berada diluar penerimaan $\mathrm{H}_{0}$ karena $z_{\text {hitung }}>z_{\text {tabel }}$ maka $\mathrm{H}_{\mathrm{i}}$ diterima. Dari kedua pengujian hipotesis tersebut dapat disimpulkan bahwa kemampuan pemecahan masalah matematis siswa yang menggunakan strategi scaffolding lebih baik dari kemampuan pemecahan masalah matematis yang diajarkan dengan pembelajaran kurikulum 2013.

Penerapan strategi scaffolding pada kelas eksperimen didapat gambaran siswa lebih termotivasi untuk belajar dan siswa aktif untuk bertanya sehingga siswa lebih leluasa dalam mengasosiasikan ide-ide atau gagasan-gagasan mereka. Hal ini terlihat dari aktivitas siswa selama proses pembelajaran dalam menyelesaikan soal yang diberikan, siswa berusaha memahami mengenai soal yang diberikan dan siswa yang sudah paham mau berbagi pengetahuan dengan siswa yang belum paham sehingga siswa mampu belajar secara mandiri dalam menyelesaikan soal atau masalah yang diberikan. Hal ini juga sesuai dengan pendapat [4] mengemukakan "Scaffolding adalah interaksi antara orang-orang dewasa dan anak-anak yang memungkinkan anak-anak untuk melaksanakan sesuatu di luar usaha siswanya". Interaksi sosial yang terjadi di kelas ketika saling bertukar pendapat antar siswa dalam memecahkan masalah tersebut, maka terjadi scaffolding. Pada pembelajaran matematika siswa diharapkan mampu merancang soal ke dalam model matematika dan mengaplikasikan konsep-konsep serta 
prinsip-prinsip matematika yang telah dipelajarinya berdasarkan kemampuannya secara individu melalui proses internalisasi untuk mendapatkan pengetahuan baru, yang bertujuan untuk meningkatkan pemecahan masalah matematis siswa.

Peningkatan pemecahan masalah matematika di kelas eksperimen terlihat dari hasil belajar siswa yang meningkat dari tiap pertemuan. Ketika guru memberikan soal latihan banyak diantara siswa kelas eksperimen yang mampu menjawabnya. Siswa lebih antusias dalam belajar dan bertanya apabila tidak paham dengan materi yang dipelajari, sedangkan pada kelas kontrol apabila diberikan soal latihan banyak diantara siswa yang tidak mampu menyelesaikannya, bahkan kebanyakan dari siswa hanya menyalin hasil kerja temannya saja dan siswa juga malas bertanya apabila tidak mengerti dengan materi yang dipelajari.

Pembelajaran pada kelas eksperimen ditekankan pada pembelajaran dimulai dari mengarahkan siswa untuk dapat memahami materi yang diberikan. Hal tersebut memberikan pemahaman yang jelas bagi siswa dan menumbuhkan keberanian mereka untuk mengungkapkan ide-ide matematika. Cara-cara penyelesaian masalah yang muncul dari aktivitas matematika siswa kelas eksperimen mendorong mereka untuk lebih aktif mengkonstruksi gagasannya. Hal tersebut dapat melatih dan mengembangkan pemecahan masalah matematis siswa serta mengarahkan mereka pada level berfikir yang lebih tinggi.

Berdasar penelitian terdahulu [5] juga memperoleh kesimpulan bahwa "Scaffolding merupakan suatu cara yang dapat digunakan guru untuk meminimalis kesulitan siswa dalam belajar matematika ataupun dalam pemecahan masalah matematika. Belajar dalam konstruktivis adalah bentukan hasil pikiran siswa sendiri, oleh karena itu scaffolding yang diberikan guru bukanlah menyelesaikan masalah siswa tetapi merupakan merupakan bantuan atau arahan dengan mengkaitkan kesulitan siswa dalam ZPD untuk meningkatkan perkembangan kemampuan potensial. [8] juga memperoleh kesimpulan bahwa "Scaffolding dapat meningkatkan pemahaman konsep dan motivasi dari siswa dan Scaffolding juga dapat membuat siswa menjadi lebih mandiri." Hasil penelitian [9] menunjukkan bahwa "kemampuan representasi matematis peserta didik meningkat secara signifikan setelah peserta didik mendapatkan scaffolding dalam pembelajaran matematika berbasis kearifan budaya Osing Banyuwangi. Demikian juga dengan hasil belajar peserta didik. Hal ini dapat dilihat dari kemampuan peserta didik dalam mengorganisasikan pengetahuannya untuk: (1) melakukan pergeseran dari bentuk representasi gambar ke representasi simbol; (2) melakukan pergeseran dari bentuk representasi simbol ke representasi verbal; dan (3) menggunakan representasi gambar guna menjelaskan ide-ide matematika. Melalui penerapan scaffoldingdalam pembelajaran matematika berbasis kearifan budaya Osing Banyuwangi, pembelajaran matematika menjadi lebih variatif, kreatif, aktif, dan pada akhirnya dapat memperluas wawasan peserta didik tentang pentingnya mengenal dan melestarikan budaya yang ada di Indonesia, terutama di wilayah Banyuwangi."

Berikut hasil jawaban perbedaan pemecahan masalah matematis siswa kelas eksperimen dan kelas kontrol pada masing-masing indikator pemecahan masalah matematis yang diamati dalam penelitian ini.

\section{Memahami Masalah}

Berikut disajikan perbedaan kemampuan siswa kelas eksperimen dan kelas kontrol dalam memahami masalah dapat diamati pada jawaban siswa pada soal nomor 1. Berikut ini disajikan penyelesaian oleh siswa pada Gambar 1 dan 2. 


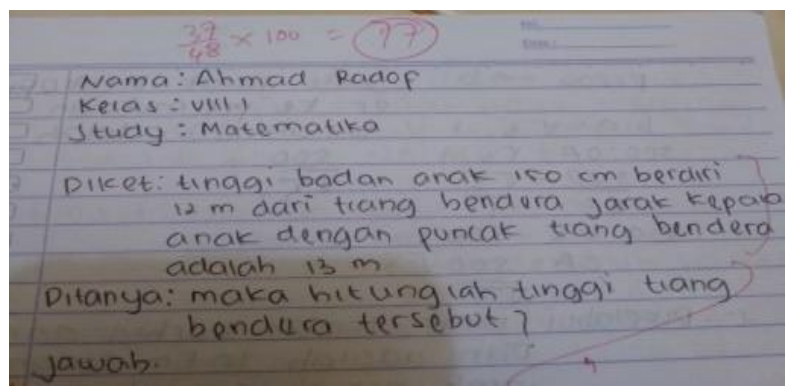

Gambar 1. Jawaban siswa I indikator A

Berdasarkan Gambar 2 siswa sudah mampu memahami masalah. Siswa dapat merancang soal tersebut ke dalam model matematika, dimana siswa bisa menentukan dan mengidentifikasi unsur-unsur yang diketahui dan ditanya dalam soal tersebut. Sehingga siswa memperoleh jawaban yang benar dari permasalahan yang diberikan.

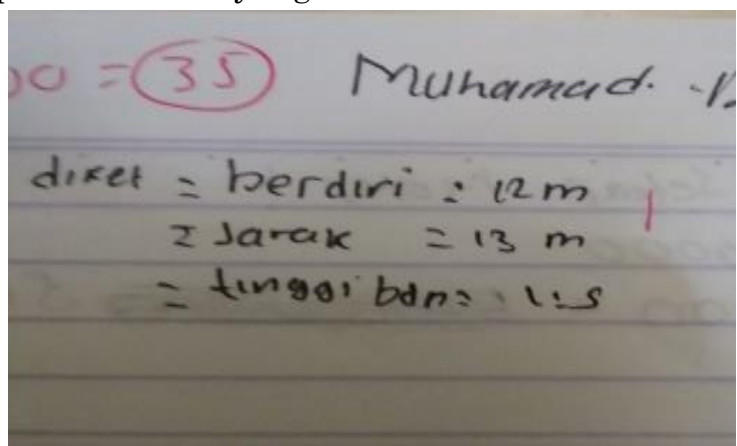

Gambar 2. Jawaban Siswa II Indikator A

Pada Gambar 3 bobot yang diperoleh siswa kurang karena siswa belum mampu menentukan dan mengidentifikasi unsur-unsur yang diketehui dan yang ditanya dalam soal yang diberikan.

\section{Merencanakan Strategi Penyelesaian Masalah}

Berikut ini disajikan penyelesaian soal oleh siswa. Perbedaan pemecahan masalah matematis siswa kelas eksperimen dan kelas kontrol dalam merencanakan strategi penyelesaian masalah dapat diamati dari jawaban siswa pada soal nomor 1. Berikut ini disajikan penyelesaian soal oleh siswa pada Gambar 3 dan 4.

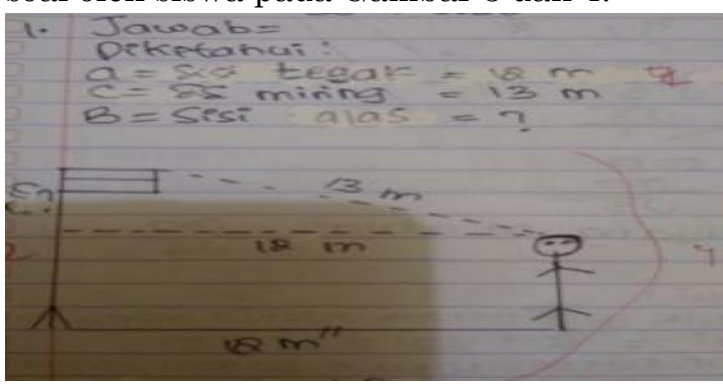

Gambar 3. Jawaban Siswa 1 Indikator B

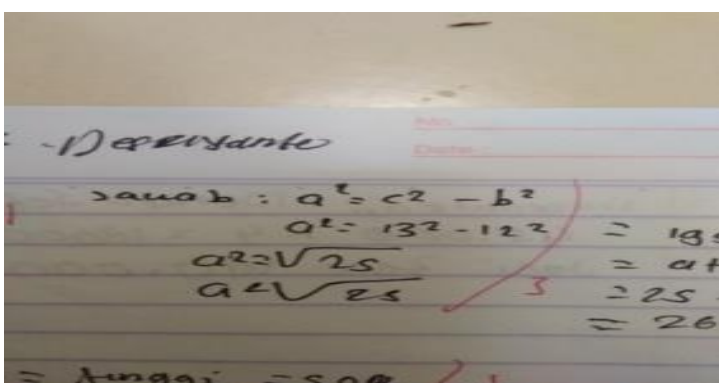

Gambar 4. Jawaban Siswa II Indikator B

Berdasarkan Gambar 3 siswa telah mampu merencanakan strategi penyelesaian masalah. Siswa dapat menyusun strategi dalam memyelesaikan soal yang diberikan, dimana siswa mampu membuat bentuk gambar dari soal cerita serta siswa dapat menyusun strategi yang sesuai untuk menyelesaikan soal tersebut. Hal tersebut menunjukan bahwa siswa telah mampu merencanakan strategi penyelesaian masalah. Pada Gambar 4 siswa belum mampu 
merencanakan strategi penyelesaian masalah. Sehingga jawaban yang diperoleh siswa menjadi salah.

\section{Pelaksanaan Rencana Strategi Penyelesaian}

Berikut ini disajikan penyelesaian soal oleh siswa. Perbedaan pemecahan masalah matematis siswa kelas eksperimen dan kelas kontrol dalam pelaksanaan strategi penyelesaian masalah dapat diamati dari jawaban siswa pada soal nomor 1. Berikut ini disajikan penyelesaian soal oleh siswa pada Gambar 5 dan 6.

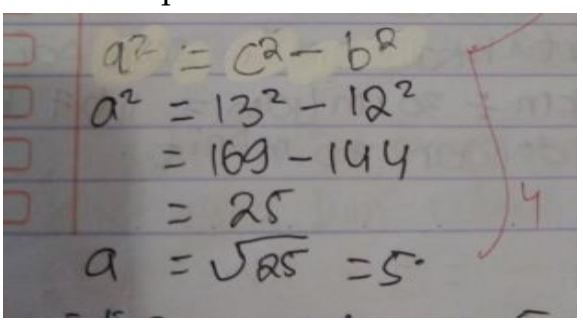

Gambar 5. Jawaban Siswa I indikator C

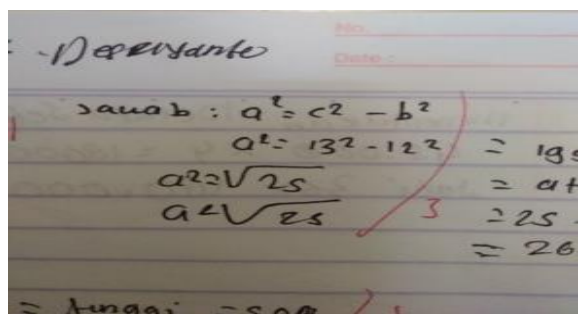

Gambar 6. Jawaban Siswa II Indikator C

Berdasarkan Gambar 6, jawaban yang diberikan menunjukkan langkah-langkah penyelesaian soal yang jelas dan mudah dipahami. Hal tersebut menunjukkan bahwa siswa kelas ekperimen sudah dapat menyelesaikan rencana strategi penyelesaian. Pada Gambar 7, langkah-langkah siswa dalam menjawab soal kurang tepat karena dalam penyelesaiannya siswa kurang jelas dalam menurunkan langkah-langkah yang dibuat, akibatnya siswa salah dalam menyelesaikan soal.

\section{Memeriksa Kembali Hasil Penyelesaian}

Berikut ini disajikan penyelesaian soal oleh siswa. Perbedaan pemecahan masalah matematis siswa kelas eksperimen dan kelas kontrol dalam memeriksa kembali hasil penyelesaian dapat diamati dari jawaban siswa pada soal nomor 1. Berikut ini disajikan penyelesaian soal oleh siswa pada Gambar 8 dan 9.

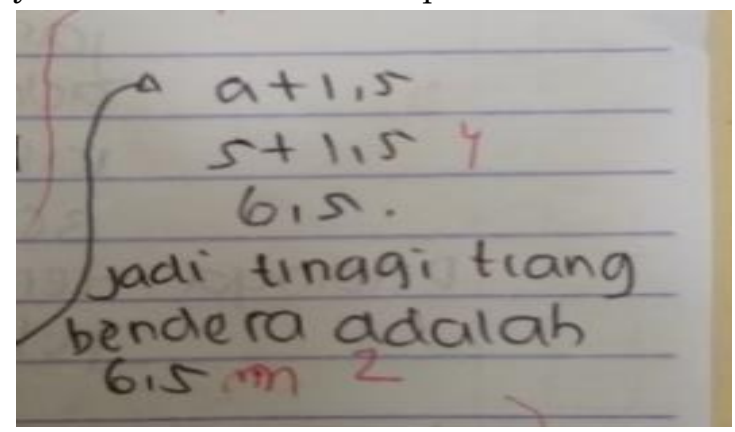

Gambar 8. Jawaban Siswa I Indikator D

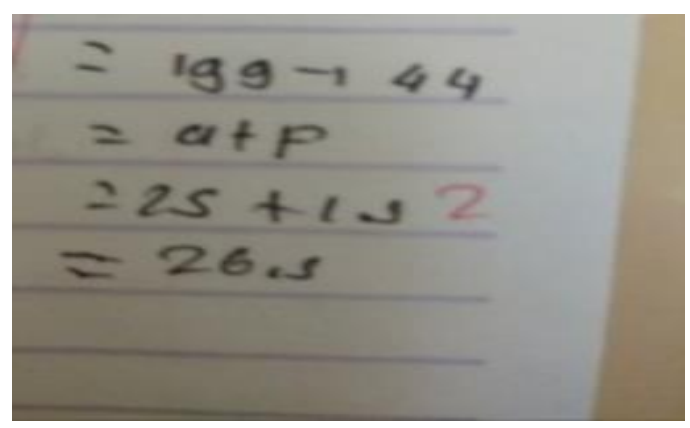

Gambar 9. Jawaban Siswa II Indikator D

Berdasarkan Gambar 8, terlihat bahwa siswa telah mampu menyajikan solusi secara rinci dan benar. Hal tersebut menunjukkan bahwa siswa kelas ekperimen sudah dapat melihat langkahlangkah penyelesaian dari masalah yang diberikan. Pada Gambar 9, siswa telah mampu menyajikan solusi namun, siswa tidak memperhatikan penyelesaian yang dibuat. Akibatnya siswa salah dalam menyelesaikan soal.

Kendala yang dihadapi selama penelitian yaitu pada pertemuan pertama ketika siswa diminta untuk bertanya siswa masih malu mengeluarkan pendapat karena mereka belum terbiasa, siswa banyak yang tidak serius dalam memahami materi serta dalam membagi kelompok siswa lebih banyak bermain-main dan hanya beberapa siswa yang mengerjakan tugas yang diberikan. Pertemuan berikutnya, siswa terlihat lebih antusias dan semangat mengikuti 
pembelajaran. Untuk mengatasi hal tersebut guru memotivasi siswa agar tidak ragu dalam mengasosiasikan ide dan gagasannya secara luwes. Guru juga menyarankan siswa untuk membaca materi pelajaran di rumah dan pertemuan berikutnya kendala tersebut dapat diatasi. Walaupun terdapat kendala selama penelitian, namun banyak peningkatan dari pertemuan pertama hingga pertemuan terakhir. Secara keseluruhan penerapan strategi scaffolding dapat meningkatkan kemampuan pemecahan masalah siswa dalam belajar sehingga meningkatkan hasil belajar matematika siswa.

\section{Kesimpulan}

Berdasarkan hasil penelitian dan pembahasan dapat disimpulkan bahwa kemampuan pemecahan masalah matematis siswa yang menggunakan strategi scaffolding lebih baik dari daripada menggunakan pendekatan saintifik di kelas VIII SMP. Berdasarkan kesimpulan yang diperoleh dalam penelitian ini, dapat dikemukakan beberapa saran sebagai berikut: (a) Strategi scaffolding dapat digunakan sebagai salah satu alternatif bagi guru dalam meningkatkan kemampuan pemecahan masalah matematis siswa dan hasil belajar siswa. (b) Penelitian ini hanya melihat hasil belajar siswa pada ranah kognitif saja. Untuk penelitian lebih lanjut juga bisa dilakukan pada ranah afektif dan ranah psikomotor.

\section{Daftar Pustaka}

[1] E. dkk Suherman, Strategi Pembelajaran Matematika Kontemporer. 2003.

[2] R. Siagian, "Pengaruh Minat dan Kebiasaan Belajar terhadap Prestasi Belajar Matematika," J. Form., vol. 2, no. 2, pp. 122-131, 2012.

[3] Fadillah, Implementasi Kurikulum 2013 dalam Pembelajaran SD/MI, SMP/MTS, \& SMA/MA. Yogyakarta: Ar-Ruzz Media., 2014.

[4] A. N. Cahyo, Panduan Aplikasi Teori-Teori Belajar Mengajar. Yogyakarta: DIVA Press, 2013.

[5] Z. Chairani, "Scaffolding dalam Pembelajaran Matematika.," Math Didact. J. Pendidik. Mat., vol. 1, no. 1, pp. 39-44, 2015.

[6] H. Ulya, "SCAFFOLDING BERBASIS KEARIFAN LOKAL SEBAGAI UPAYA," pp. 56-69, 2017.

[7] A. dkk Prayitno, "Pemberian Scaffolding Berdasarkan Kesalahan Berpikir Siswa Dalam MATEMATIKA,” no. December 2018, 2019, doi: 10.15642/jrpm.2018.3.2.161-172.

[8] W. Retnodari, "Scaffolding dalam Pembelajaran Matematika," Math. Educ., vol. 1, no. 1, pp. 15-21, 2020.

[9] E. Poetri Astutik, "SCAFFOLDING DALAM PEMBELAJARAN MATEMATIKA BERBASIS REPRESENTASI MATEMATIS SISWA Scaffolding in Mathematic Learning Based on the Wisdom of Banyuwangi Osing Culture to Improve Student's Mathematical Representation," vol. 24 , no. 1 , pp. $49-58,2020$. 